DOI https://doi.org/10.36059/978-966-397-226-8-4

\title{
METHODS OF FOREIGN LANGUAGE REMOTE TEACHING
}

\section{Railianova V. E.}

\section{INTRODUCTION}

Any science has fundamental concepts that are the starting point for people using the material of this science. These concepts are called basic categories. In the field of methods of foreign language teaching, the basic categories are considered to be a technique, a method in the narrow sense of the word, means and a system.

A technique is a methodical act aimed at solving a specific problem ${ }^{84}$. Each lesson in a foreign language, regardless of the stage of training, consists of a variety of techniques aimed at undergraduates' awareness of the introduced language phenomenon, their inclusion in active during material training, and management of undergraduates' independent speech activity. Techniques are differentiated depending on the level of knowledge that undergraduates have, the stage of training, working conditions and the skill of the academic staff member. In the use of technique, the interaction of an academic staff member and undergraduate is most clearly revealed. Adequately chosen and skillfully applied technique ensures good results for undergraduates' work.

A teaching method is a way of teaching and learning activities that best meets the goals and objectives of the educational process ${ }^{85}$. The method is used in cases where the constant repetition of the same work techniques is practiced to achieve the goal of mastering a foreign language.

The term "method" is used in the methodology of foreign language teaching in two meanings: in the narrow sense - as one of the methods of teaching, in the broad sense - as a methodological system. Teaching methods are largely correlated with the cognitive method, although they

\footnotetext{
${ }^{84}$ Колесникова, И. Л., $\quad$ Долгина, О. А. $\quad$ (2001). Англо-русский терминологический справочник по методике преподавания иностранных языков. С.-П. : БЛИЦ. С. 21.

${ }^{85}$ Колесникова, И. Л., Долгина, О. А. (2001). Англо-русский терминологический справочник по методике преподавания иностранных языков. С.-П. : БЛИЦ. С. 23.
} 
cannot be identified with them. British researchers D. Richards and G. Rogers made a significant contribution to the development of the theory of the method of foreign language teaching and identified the following levels of the method: theoretical, or level of approach (approach), level of development (design) and level of practical application (procedure) ${ }^{86}$.

When teaching foreign languages in the activities of academic staff and undergraduates, the main and related methods are distinguished. In the activities of academic staff members, the main methods are as follows: showing, explaining (highlighting landmarks or organizing their search by students themselves), training, and the use of language material in practice. Each of these basic methods is accompanied by control, including correction and evaluation.

In the activities of undergraduates, the basic methods of cognition include: familiarization, comprehension, articulation, observation; blurring, suggesting awareness of the selected landmarks or their independent search; training corresponding to conditioned speech activity; the use of different types of speech activities, correlated with practice in natural conditions. Each of these basic teaching methods is accompanied by self-control, which includes self-correction and self-esteem.

When comparing the concepts of "method" and "technique", we find that the method is associated with the main activity (familiarization, training, application), and the technique is associated with a specific action (methods of uninterrupted semantization, developing a response to a speech stimulus, building a sentence according to a grammatical rule or structural model, developing purity sounding speech and intonational oppositions).

Means for teaching a foreign language are basic and auxiliary teaching materials that ensure the educational process. The main means of teaching a foreign language is a teaching and methodological complex: it contains a language minimum defined by the program for a particular level of knowledge, texts differentiated by forms of communication - oral dialogue, oral monologue, written monologue -

\footnotetext{
${ }^{86}$ Richards, D., Rogerds, G. (1995). Approaches and methods of language teaching. Cambridge University Press. P. 29.
} 
and suitable, along with exercises, for the development of skills by types of speech activity.

Learning aids are audible, visual, audiovisual teaching materials. The use of aids in teaching a foreign language activates educational process, makes teaching more visual, more accessible, emotional and effective. Use of technical teaching aids brings undergraduates closer to natural language environment.

The teaching system is a complete set of components corresponding to a specific methodological concept; it determines the goals, content, principles, methods, techniques, means, forms of organization of teaching and, in turn, is conditioned by them. Regarding teaching foreign languages, the concept of a system includes the initial provisions of teaching, the activities of the academic staff member, undergraduates and teaching aids. The integrity of the system is ensured by various connections between its elements and their interaction during the functioning of the system. All these components in combination should provide the expected result - a certain level of awareness in speech activity provided by this system.

\section{Productive types of speech activities}

\subsection{Writing}

When considering types of speech activity, from the point of view of linguistics, psychology, psychophysiology, psycholinguistics, methods of teaching foreign languages, their similarities and differences are observed. Each speech skill is characterized by a certain set of features; identifying the maximum number of these features in each speech skill constitutes a typological characteristic of the auditory skill, ability to speak, read, write. Choice of effective teaching methods of perception and production of speech is associated with understanding the similarities and differences between receptive and productive types of speech activity.

Expression of thoughts in oral and written form is productive type of speech activity which is in many aspects similar, but also in many aspects different, and this fact is reflected in foreign languages teaching. Their main similarity is that speaking and writing serve the purpose of giving out information. Most similar to each other is written and oral 
monologue. Speech messages representing them are generated as a result of similar actions and operations.

Learning to write (the term "writing" is used here in a broad sense of the word to refer to writing as a process and writing as kind of speech) includes work on the technique of writing (graphics, spelling, punctuation) and the written expression of thoughts in the target language (productive written speech). Teaching how to write is aimed at developing the ability to express thoughts in writing using the material being studied; writing is also used to consolidate knowledge and develop language skills. The content of the statement is embodied in a written message (coherent text). Depending on the purpose of communication and cognition, the types of written messages are distinguished. Based on classification of $\mathrm{T}$. Hedge, it is possible to distinguish main types of expressive written speech, depending on its purpose and scope of functioning, as well as types of written messages in which each of these types is implemented and which should be taught depending on specific conditions and goals ${ }^{87}$.

\section{Types of writing}

\begin{tabular}{|c|c|c|c|c|}
\hline Academic writing & $\begin{array}{c}\text { Professional } \\
\text { writing }\end{array}$ & $\begin{array}{c}\text { Social } \\
\text { writing }\end{array}$ & $\begin{array}{c}\text { Personal } \\
\text { writing }\end{array}$ & $\begin{array}{c}\text { Creative } \\
\text { writing }\end{array}$ \\
\hline essays & business letters & notes & diaries & poems \\
research reports & progress reports & letters & journals & stories \\
summaries & resumes/ & invitations & reminders & rhymes \\
curriculum vitae & applications & messages & addresses & drama \\
annotations & public notices & instructions & recipes & scripts \\
abstracts & contracts & & shopping & lyrics \\
notes & memoranda & & lists & \\
& minutes & & packing & \\
& advertisements & & lists & \\
& articles & & & \\
& & & & \\
\end{tabular}

${ }^{87}$ Hedge T. (1993). Writing. Oxford : OUP. P. 96. 
Academic writing can be defined as a written speech used for educational (academic) purposes. Such written speech messages as essays, reviews, summaries refer to this type of writing.

Professional writing can be defined as type of written speech which is used for professional purposes and normally implemented in such speech works as business letters, contracts, public notices, reports, articles, etc.

Social writing type of written speech which is used to maintain social messages in the form of notes, private letters, short message services (sms), electronic messages (e-mail messages), etc.

Personal writing is type of written speech used for personal purposes for the form of reminders, recipes, notes, etc.

Creative writing is written speech represented in poetry, stories, scenerias, etc.

\subsection{Remote teaching: methods of teaching writing}

Learning to write includes working with writing techniques and writing thoughts in target language. To develop the ability to express thoughts correctly, it is advisable to conduct training and control in the following sequence:

\begin{tabular}{|c|c|}
\hline \multicolumn{2}{|c|}{ Sequence of activities for developing writing skills } \\
\hline Step 1 & plan \\
\hline Step 2 & synopsis \\
\hline Step 3 & summary of the text that was read \\
\hline Step 4 & non-critical presentation of its content \\
\hline Step 5 & critical presentation of its content \\
\hline Step 6 & annotation \\
\hline Step 7 & abstract on a series of texts \\
\hline Step 8 & essay \\
\hline
\end{tabular}

Written speech is pre-formed in thought and involves a large number of mental actions and operations. The process begins with drawing up a program of future statement in inner speech. It includes mental activity for selection of lexical units, organizing them into grammatically formalized sentences and combining structures into large chunks of speech - paragraphs - to reveal logical connections between separate 
thoughts. All these activities are normally conducted by undergraduates at home and therefore shifting from face-to-face to distance learning hasn't affected dramatically methods of teaching writing. But anyway, it brought certain difficulties both for undergraduates and undergraduates.

No matter what type of speech activity we discuss, the first problem is to keep students motivated and learner-centered environment is considered to be the key. Thus, while teaching writing online algorithm should be as follow:

\begin{tabular}{|c|c|}
\hline \multicolumn{2}{|c|}{ Teaching writing online: algorithm } \\
\hline Step 1 & Identify the purpose of writing in your undergraduates' real life \\
\hline Step 2 & $\begin{array}{c}\text { Connect themes for their written work to situations } \\
\text { from their real life }\end{array}$ \\
\hline Step 3 & $\begin{array}{c}\text { Develop a good rapport with you undergraduates and keep } \\
\text { them connected with each other (for consultation/advise) }\end{array}$ \\
\hline Step 4 & $\begin{array}{c}\text { Use visual materials (such as photos or pictures) } \\
\text { to activate their mental activity }\end{array}$ \\
\hline Step 5 & $\begin{array}{c}\text { For each type of writing provide short and clear plan that they } \\
\text { must use while writing and give links for online samples }\end{array}$ \\
\hline Step 6 & $\begin{array}{c}\text { Identify vocabulary and grammatical structures } \\
\text { that they should use in their written work }\end{array}$ \\
\hline Step 7 & Set a deadline \\
\hline Step 8 & Assess their work \\
\hline
\end{tabular}

Teaching to write is a complex and time-consuming process, no matter whether you work in a real or virtual classroom, but modern technologies allow to make it closer to real life interests of your undergraduates and the efforts spent on overcoming difficulties in mastering writing will pay off.

\subsection{Speaking}

Speaking is a productive (expressive) type of speech activity, through which oral and verbal communication is carried out along with listening ${ }^{88}$. Foreign speaking as a complex integrated skill is

\footnotetext{
${ }^{88}$ Колесникова, И. Л., $\quad$ Долгина, О. А. (2001) Англо-русский терминологический справочник по методике преподавания иностранных языков. С.-П. : БЛИЦ. С. 106.
} 
distinguished by motivation, activity and independence of the speaker, purposefulness, connection with thinking, situational conditioning, heuristicity ${ }^{89}$. The content of speaking is the expression of one's own and others' thoughts, directed to one or an unlimited number of persons, using lexical and grammatical material in speech interrelation. In real communication, speaking performs three main functions: 1) is an integral part of oral dialogue; 2) can be used as speech action aimed at satisfying human needs in transmission of information, influencing the interlocutor, prompting the interlocutor to provide the necessary information in sound form; 3) plays a role of an integral component of person's professional activity (lecturers, leaders, actors, presenters, etc.).

A person's ability to speak and write exists autonomously in terms of synchronicity, however, they can overlap. An important oral communication (report, presentation) is prepared in advance in writing. A message presented orally that is scientifically or socially significant is outlined upon perception.

As an independent type of speech activity, speaking provides oral communication in foreign language in dialogical form, combining with listening and monologue. Operations and actions that ensure functioning of speaking as a type of speech activity occur in the following sequence: 1) programming message in which motives and tasks of the statement are clarified, the message is formed in images, schemes and concepts; 2) verbalization of the message program in internal speech, when the thought fits into the grammatical structure, and the words take the appropriate morphological forms; 3) the embodiment of the message in sounds of external speech, according to the mode of breathing, voice formation and articulation of the language of speaking.

Speaking and writing differ in level of complexity of actions and operations that take place when generating oral dialogue, oral monologue and written monologue. With possession of speech skills, participation in a dialogue is associated with less energy consumption than a monologue statement. However, when mastering a foreign language, the situation is different: it turns out to be more difficult to teach a dialogue than

\footnotetext{
${ }^{89}$ Пассов, Е. И. (1989). Основы коммуникативной методики обучения иноязычному общению. М. : Русский язык. С. 125.
} 
a monologue. This is due to the fact that the dialogue requires a high degree of automation in the handling of linguistic material and the development of ability to listen, follow the thought of interlocutor, and quickly and properly respond to a given situation. When preparing for a dialogue, you can think through only the first two or three remarks. Further development of the dialogue is controlled only by communication situation.

Thus we can single out two forms of speaking process: dialogue and monologue, and a complex interrelation of dialogue and monologue. And therefore, speaking skill includes two groups of specific skills: dialogical (or conversastional) and monologue.

\section{Types of speaking skills}

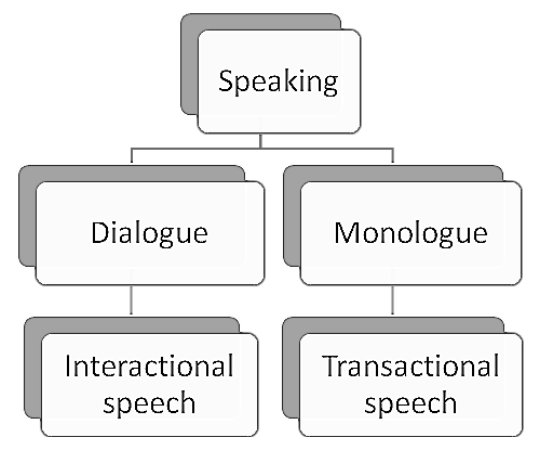

Interactional speech is form of speaking, the main purpose of which is interaction between two or more speakers. This form of oral speech correlates with dialogical speech, which is a process of direct verbal communication, characterized by alternately replacing one another by the replicas of two or more persons.

Transactional speech is form of speaking aimed at conveying information.

One of the definitions of speaking as a complex cognitive skill is indicative: "Speaking is an example of a complex cognitive skill which can be differentiated into various hierarchical sub-skills, some of which 
might require controlled processing while others could be processed automatically" 90 .

\subsection{Remote teaching: methods of teaching speaking}

Speaking as a type of speech activity is a process of forming, formulating and transmitting in sound form one's own and others' thoughts, directed to one or an unlimited number of persons, using lexical and grammatical material in speech interrelation. When teaching speaking, an academic staff member must organize her or his activities in such a way that he can creatively use teaching aids, not to abuse samples of written monologue in teaching oral monologue, and even more so in dialogue or conversation. Teaching speaking involves mastering linguistic material, creating the habit of using foreign language in communication and formation of mechanisms for production of unprepared and prepared speech. Skills and abilities of unprepared speech, its spontaneity and pace are developed in dialogue; skills and abilities of prepared speech with its initiative, consistency, consistency - in monologue.

As we mentioned above, monologue as a type of speech activity can be represented both in oral and in written form. It should follow all the rules for constructing, can be pre-planned, prepared, coherent address to listeners in order to convey information, share opinions, argue a point of view, convince. Therefore, remote teaching did not influence dramatically the way of teaching of this type of speaking activity. This is dialogue and conversation that many educators find difficult to teach online. Conversation is an informal, usually private, talk in which two or more people exchange thoughts, feelings, or ideas, or in which news or information is given or discussed ${ }^{91}$. Conversations are typically categorised by action sequences and it is also co-constructed because a few people are involved in conversation, it is spontaneous and nobody is sure where this is going. But in learning environment an academic staff member is the one who controls it on each step of its development. While teaching speaking online principles remains unaltered.

\footnotetext{
${ }^{90}$ O’Malley, B., Chamot, A. (1995). Teaching learning strategies to language students. Cambridge University Press. Pp. 66-67.

${ }^{91}$ Cambridge dictionary. Conversation.
} 


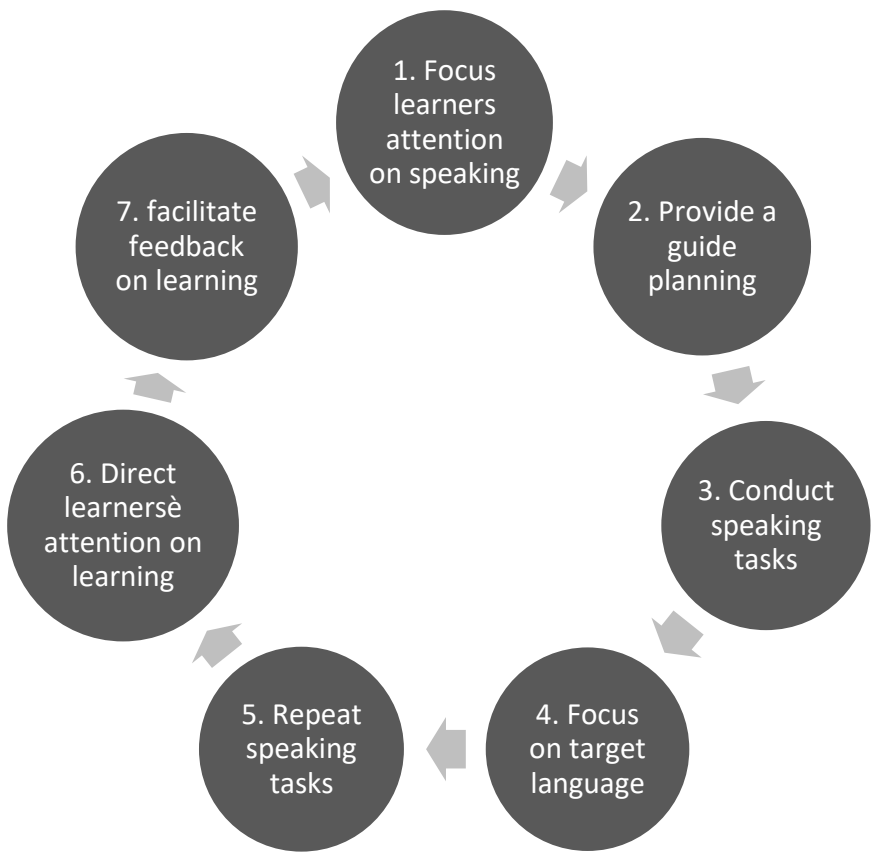

Creation of a learner-centered content is of great importance for both types of teaching. The idea is to reflect the content from learners. It allows bringing engagement and motivates students to speak and develop conversational skills.

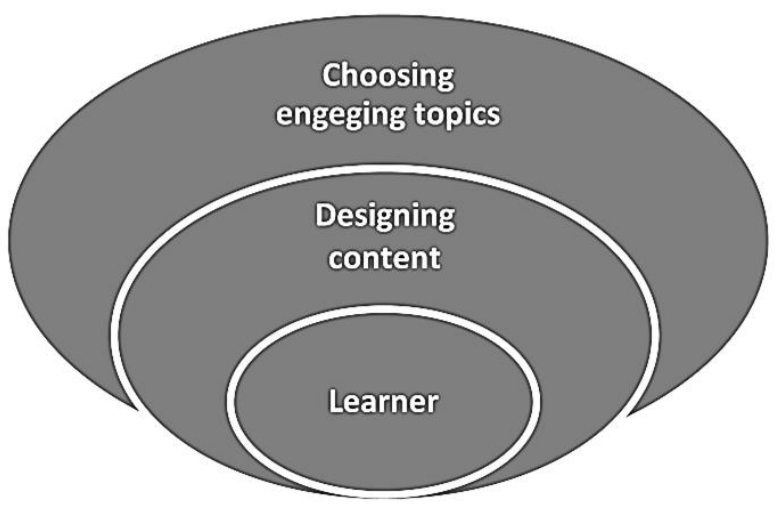


One more thing that modern methodists pay special attention to is immersive environment.

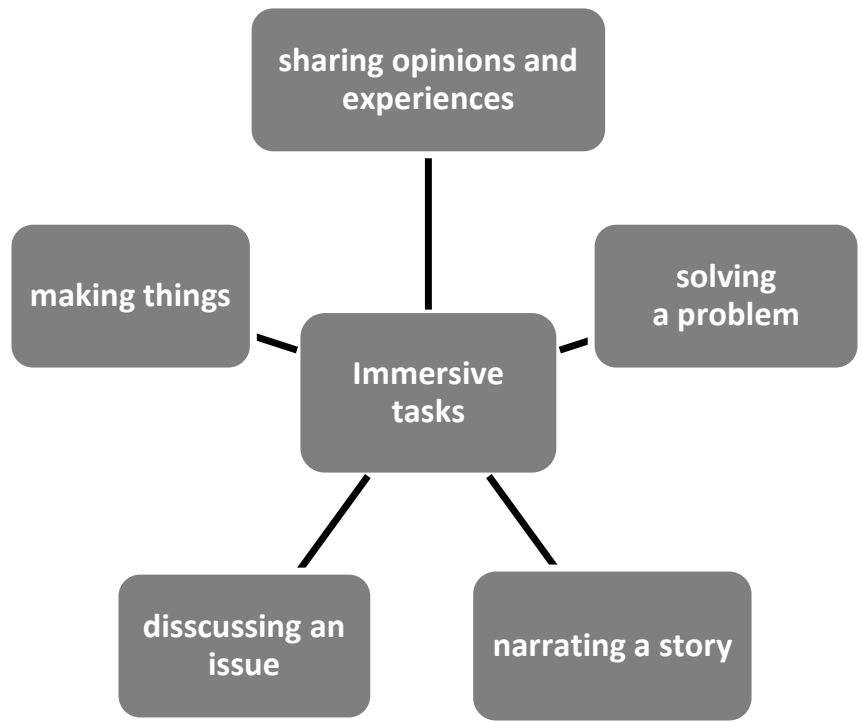

It may be quite difficult to create this immersive environment for some reasons. But in some ways, perhaps creating immerse environment is more about replicate and become a real world context of feelings.

Conversation is about interaction, about how we bring undergraduates together, how we use near-peers and varied interaction. If we put all mentioned above points and apply them at our online classes, we may have the following act of communication:

\section{Developing conversation with immersive online tasks}

\begin{tabular}{|c|c|}
\hline Step 1 & $\begin{array}{c}\text { Identify a global issue that interests your students and identify } \\
\text { a number of YouTube videos on the topic to share with them }\end{array}$ \\
\hline Step 2 & Undergraduates watch the videos on the topic for homework \\
\hline Step 3 & $\begin{array}{c}\text { In online class, break undergraduates into breakout rooms } \\
\text { in pairs or groups of three }\end{array}$ \\
\hline Step 4 & $\begin{array}{c}\text { Give the undergraduates a task of solving the global problem } \\
\text { in their pairs/groups }\end{array}$ \\
\hline Step 5 & Get undergraduates to record their conversations \\
\hline
\end{tabular}




\begin{tabular}{|c|c|}
\hline Step 6 & $\begin{array}{c}\text { Bring the undergraduates back to class and ask each group } \\
\text { to share their proposed solutions (could include } \\
\text { an outline/small presentation/graphics) }\end{array}$ \\
\hline Step 7 & $\begin{array}{c}\text { Get undergraduates to vote on the best solution using } \\
\text { a polling feature if you have it }\end{array}$ \\
\hline Step 8 & $\begin{array}{c}\text { For homework, get the undergraduates to listen back } \\
\text { to their recordings. Ask them to do the following as part } \\
\text { of their own learning development* }\end{array}$ \\
\hline
\end{tabular}

*Tasks for undergraduates for learning development:

- note down how many words they used that they learned this week;

- notice a particular language feature you think is important for them (how they ask and answer questions, how they show (dis)agreement, etc.);

- reflect on any breakdowns in communication, what went wrong and how it could be improved.

Looking at this plan from methodological and pedagogical point of you we can identify the following techniques are applied:

\begin{tabular}{|c|c|}
\hline Step 1 and 2 & Personalized and learner-centered task \\
\hline Step 3 & $\begin{array}{r}\text { Near-peer role models, varied interaction, } \\
\text { effective use of technology }\end{array}$ \\
\hline Step 4 & Immersive task, collaborative, interthinking \\
\hline Step 5 & Effective use of technology \\
\hline Step 6 & Effective use of technology, safe-space \\
\hline Step 7 & Interactive, engaging, effective use of technology \\
\hline Step 8 & $\begin{array}{c}\text { Reflection and self-evaluation (metacognition), noticing, } \\
\text { forward thinking, effective use of technology }\end{array}$ \\
\hline
\end{tabular}

Such component of any lesson as assessment is admitted to be very important and in online classes its significance grew up. Control of skills in teaching speaking is aimed at determining degree of assimilation of language material and ability to intuitively operate it. Indicators of the level of speech skills is speed of verbal reaction, number, duration and localization of pauses, rate of utterances, speed and quality of selfcorrection of mistakes made as a result of correlating speech implementation with the utterance program. Control and assessment is an integral part of any online class. 


\section{Receptive speech activities}

\subsection{Listening comprehension}

Listening and reading are receptive types of speech activity. Their main similarity lies in the fact that they serve to receive information. Listening and reading, representing, respectively oral and written speech, flow in different conditions and as types of speech activity have a number of significant differences. The data of physiological and psychological studies indicate that listening, compared to reading, is a more difficult way to obtain information. The fluidity and irreversibility of the oral message make it impossible to analyze retrospectively, as a result irreplaceable gaps may appear in the received information. An oral message is perceived and comprehended simultaneously. The linguistic form is perceived intuitively, without analysis, consciousness is aimed at the semantic content of speech. In contrast, the reader can repeatedly return to incomprehensible places in the text, re-read them, analyze, pause in reading in order to comprehend what he has read.

Listening as a type of speech activity is the simultaneous perception of a sounding text, recognition of lexical and grammatical structures in speech interrelation, understanding of the content and meaning in general, while presenting them simultaneously ${ }^{92}$. In real communication, listening performs three main functions: 1) is used as a speech action aimed at satisfying person's needs in receiving information by ear, which is part of her or his personal and professional activity; 2) is a component of oral communication in conversation, dialogue, dispute; 3) can act as a concomitant speech action of the speaker, reading, writing, while it allows to supervise your speech when speaking, writing and control over the understanding of someone's else speech when reading.

Listening includes the following auditory skills, integration of which ensures mastery of this type of speech activity:

- auditory-pronunciation skills, that is, brought to automatism ability of error-free, fast, stable simultaneous reproduction, acceptance and recognition of the phonetic code;

- receptive lexical and grammatical skills.

\footnotetext{
${ }^{92}$ Колесникова, И. Л., $\quad$ Долгина, О. А. (2001) Англо-русский терминологический справочник по методике преподавания иностранных языков. С.-П. : БЛИЦ. С. 101.
} 
Hearing and understanding are provided by mechanisms of short-term and long-term memory, probabilistic forecasting and comprehension. Short-term memory keeps information within range. Long-term memory stores stereotypes, issuing them for comparison and operation with them. Mechanism of probabilistic prediction allows to anticipate the thoughts and behavior of the speaker, thereby facilitating understanding. Mechanism of comprehension carries out equivalent substitutions, transforming verbal information into figurative one, compressing the phrase by omitting details, leaving only milestones in memory and freeing it up for the reception of subsequent information.

Listening can be divided into two types: educational and communicative, each of which in turn have a number of subcategories.

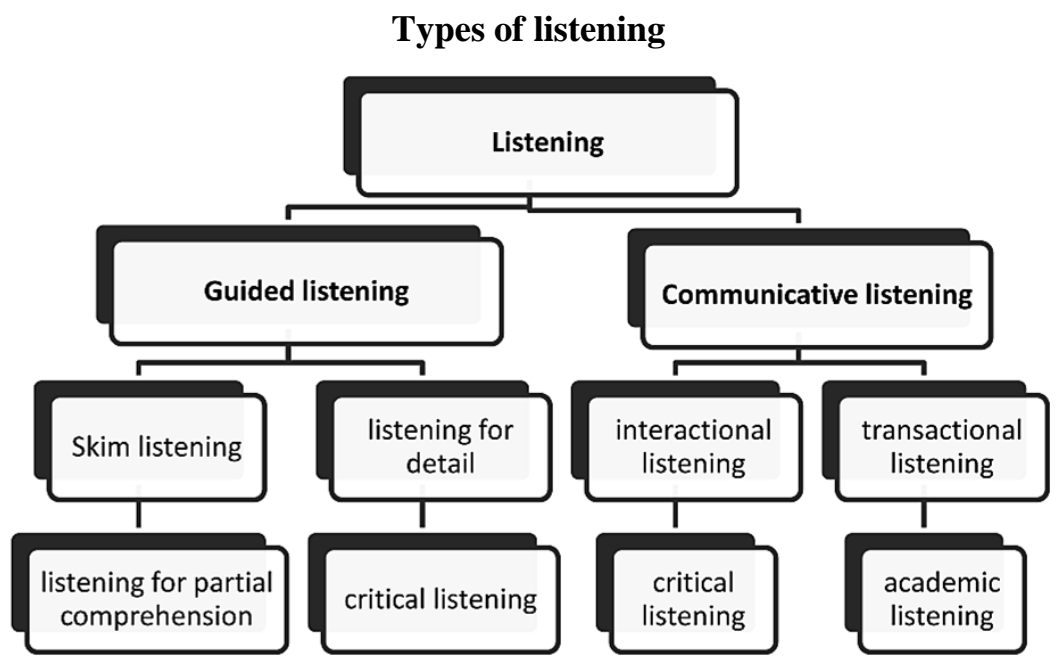

Guided listening refers to academic listening and is used as a teaching tool. It serves as a way to introduce language material, creating strong auditory images of linguistic units is a prerequisite for mastering oral speech, becoming and developing communicative listening skills.

Communicative listening is a receptive type of speech activity, aimed at the perception and understanding of oral speech by ear during listening without repetitions. 


\subsection{Remote teaching: methods of teaching listening}

Of the many difficulties of listening a foreign speech, as most widespread can be considered conditions for hearing speech, difficulty of the process of transcoding audio signals into content, limited capabilities of an inexperienced listener, and linguistic features of the sounding text. The difficulty of the auditing process itself is that it is a combination of analytical and synthetic operations to recognize language form and extract content.

Along with speaking, methods of teaching listening should be corrected in some way. And leading linguistic methodists suggest a following algorithm of working:

\begin{tabular}{|c|c|}
\hline \multicolumn{2}{|c|}{ Teaching listening online: algorithm } \\
\hline Step 1 & Tune up your undergraduates (get them adjust to your voice) \\
\hline Step 2 & $\begin{array}{c}\text { Start discussion with simple questions } \\
\text { (make them feel relax and ready for listening) }\end{array}$ \\
\hline Step 3 & $\begin{array}{c}\text { Check nobody has problems with their audio or video } \\
\text { and that all materials can be accessed on the platform }\end{array}$ \\
\hline Step 4 & Personalize and build rapport \\
\hline Step 5 & Grade your language \\
\hline Step 6 & $\begin{array}{c}\text { Involve all sources of listening : the teacher, } \\
\text { the students, the audio }\end{array}$ \\
\hline Step 7 & $\begin{array}{c}\text { Record your lesson/listening part of the lesson } \\
\text { and send to your undergraduates } \\
\text { Step 8 }\end{array}$ \\
\hline
\end{tabular}

As it is shown in the diagram sequence of activities remained almost the same: set the context; activate current knowledge; predict content; check understanding.

Thus, you can see that means of delivery changed rather than strategy.

\subsection{Reading comprehension}

Reading is a receptive type of speech activity aimed at the perception and understanding of the written text. In the process of reading, comprehension and evaluation of the information contained in the text 
takes place ${ }^{93}$. While reading, there is a recognition of the lexical and grammatical material in the speech relationship, an understanding of the integral content and meaning of the message by creating an objective image - the content of the text. In real communication, reading performs two functions: receiving information contained in the text (silent reading), and transmitting information extracted from the text to a listener (reading aloud). The first function of reading relates to listening, the second one to speaking.

Reading as a teaching tool is used to consolidate introduced language material, stabilize and improve pronunciation skills, meaningful division of speech flow and intonation, vocabulary enrichment and semantic guess, as well as the feeling of language, formation of language consciousness (understanding of how language material functions in speech), development of reading mechanisms, improvement of skills and abilities of expressing thoughts in oral and written form. Without mastering this type of speech activity, further use of foreign language outside the linguistic environment is very limited. In addition, speaking skills not supported by reading are destroyed quite fast. Reading as type of speech activity is the extraction of information from printed text. This activity is differentiated according to different criteria, which is embodied in different types of reading. According to the target orientation of activity: scanning, skimming and detailed informative reading are distinguished.

According to the method of disclosing the content: analytical, synthetic, translatable, non-translatable.

By the nature of the organization of activity: prepared, training, control reading.

Pedagogical classification draws attention to the organizational side of the educational process. Class reading and home reading are distinguished at the place of work; according to the form of organization - individual reading and group or chorus reading.

\footnotetext{
${ }^{93}$ Колесникова, И. Л., $\quad$ Долгина, О. А. (2001) Англо-русский терминологический справочник по методике преподавания иностранных языков. С.-П. : БЛИЦ. С. 95.
} 
Depending on the mental processes that accompany reading analytical reading and synthetic reading (global reading), reading aloud or oral reading and silent reading are distinguished.

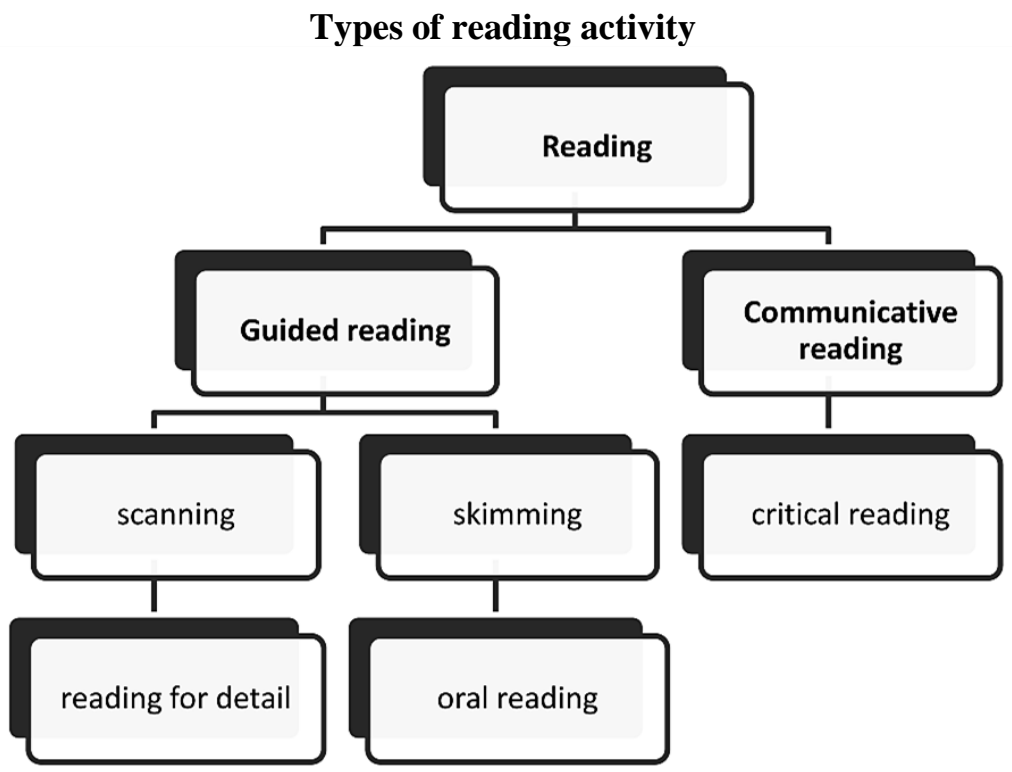

Guided reading is educational reading which is used as a teaching tool and is implemented in process of forming reading mechanisms, operations and actions that make up the processes of perception and understanding.

Communicative reading is development of communicative reading skills that is one of the main goals of teaching foreign language. Communicative reading implies such approach to written text in when reader clearly understands purpose of the forthcoming activity.

The purpose of teaching reading is to develop the ability to read informatively - silent reading, synthetic, non-translational. Other types of reading prepare its functioning as a type of speech activity and generally serve as a means of teaching a foreign language. 


\subsection{Remote teaching: methods of teaching reading}

Teaching reading as a type of speech activity requires that an academic staff member should strictly differentiate reading aloud and silent reading; give a psychological orientation to this or that phenomenon of language or the content of a text and a personal assessment of information; grade texts by difficulty, volume and type of reading; teach fast search reading; did not limit control of understanding of the text only by retelling its content.

As for remote teaching, teaching reading may have the following structure:

\begin{tabular}{|c|c|}
\hline \multicolumn{2}{|c|}{ Teaching reading online: algorithm } \\
\hline Step 1 & $\begin{array}{c}\text { Ask undergraduates simple questions that may relate } \\
\text { to the topic of the text they are going to read }\end{array}$ \\
\hline Step 2 & Introduce the topic (use high quality images) \\
\hline Step 3 & $\begin{array}{c}\text { Make sure that all text materials can be accessed } \\
\text { on the platform (worksheets with tasks to the text, } \\
\text { hyperlink to the text itself) }\end{array}$ \\
\hline Step 4 & Suggest skim reading \\
\hline Step 5 & $\begin{array}{c}\text { Further reading: scanning for specific details, intensive } \\
\text { reading, dealing with unknown words }\end{array}$ \\
\hline Step 6 & $\begin{array}{c}\text { Extension task: use technologies to activate their work } \\
\text { (Google Jam board, polls, etc.) }\end{array}$ \\
\hline Step 7 & Reflection \\
\hline Step 8 & Assess their work \\
\hline
\end{tabular}

It is important to emphasize that all types of reading are interconnected, they are intertwined and complement each other. No matter if you teach online or in a classroom, a rational methodology for teaching reading should be built taking into account all classifications of reading, and the use of different types of reading in the educational process is a means of achieving a common goal - teaching to read in a foreign language. As the most important components of teaching reading, one should consider the formation of awareness of the purpose of reading in each specific case and the choice of a reading strategy corresponding to this goal. 


\section{CONCLUSIONS}

No matter how sophisticated techniques, methods, means and systems of foreign language teaching are one must know how to apply them therefore till now the academic staff member was a central person in the classroom. But recently education and training have faced huge disruption and a quick shift to distance and online learning. Nowdays a great pressure has been experiencing both academic staff and undergraduates, and the problem is not only in the mass use of technology which has also revealed gaps and exposed weaknesses of different kinds, but also in technologies of teaching which have to be adopted for remote teaching.

We often see in online courses that undergraduates come to a virtual class with an expectation that they need to read only the textbook, communicate only with the academic staff member and be evaluated in the end of the term by answering a multiple choice quiz. However, modern methodists realise that despite certain challenges that educators come across with because of the spontaneous shift from classroom to digital environment, explicit use of technologies provides unbounded opportunities for teaching language on a new, advanced level.

\section{SUMMARY}

More and more English language teaching is taking place online these days in groups and one to one. Now the principles of teaching and learning remain the same across all contexts but methods and approaches are the subject of active discussion.

The necessity of foreign languages remote teaching has prompted the need to transform approaches and teaching skills that we use in teaching face-to-face language courses into those that could be effectively applied while remote teaching.

By all means, it is extremely important to remember that goals and objectives of foreign language teaching remain the same, they are unchanged, it is the ways to achieve them have been performing the process of transformation. Besides, it is obvious that academic staff should acquire additional, new skills too. Thus, an academic staff member, for example, ought to have a paradigm shift in perception of instructional time and be aware of virtual management techniques, or, 
taking into consideration that foreign language is the subject about interaction, have a clear idea what techniques are used for engaging undergraduates into virtual communication.

The work deals with issues of adoption of modern methods, techniques and principles of foreign language teaching for using them while teaching remotely. Each type of classroom activity now must be changed to be suitable for teaching online.

Each type of speech activity which is taught to a language undergraduate was considered, its features were analyzed and there has been suggested changes that make it possible to teach language skills remotely as effectively as possible. Main methodological problems that academic staff experience nowdays have been highlighted and suggested ways to solve them.

\section{REFERENCES}

1. Демьяненко, М. Я., Лазаренко, К. А., Мельник, С. В. (1984). Основы общей методики обучения иностранным языкам. Киев : Высшая школа. $254 \mathrm{c.}$

2. Колесникова, И. Л., Долгина, О. А. (2001) Англо-русский терминологический справочник по методике преподавания иностранных языков. С.-П. : БЛИЦ. 205 с.

3. Пассов, Е. И. (1989). Основы коммуникативной методики обучения иноязычному общению. М. : Русский язык. 254 с.

4. Clandfield, L., Hadfield, J. (2017). Interaction online. Cambridge University Press. 237 p.

5. Hedge, T. (1993). Writing. Oxford : OUP. 1993. 355 p.

6. O’Malley, B., Chamot, A. (1995). Teaching learning strategies to language students. Cambridge : CUP. 260 p.

7. Richards, D., Rogerds, G. (1995). Approaches and methods of language teaching. Cambridge University Press. $171 \mathrm{p}$.

8. Watkins, P. (2018). Teaching and developing reading skills. Cambridge University press. 327 p.

9. Cambridge dictionary. URL: https://dictionary.cambridge.org/ru. 